\title{
STATE AS A SUBJECT OF INTERNATIONAL LAW
}

\author{
Aneta Stojanovska-Stefanova* \& Drasko Atanasoski**
}

State boundaries are endpoints to where sovereignty lies within a country. The authorities within it regulate the relations inside and the nature of its international positions. The highest authority, which does not recognize any other form of higher power is sovereignty. Considering that the law, especially the international, is an active matter open to interpretation, although the basic features of a country are clear, yet there are two types of states divided to a de jure- existing under law and de factoexisting in reality, based on the matter whether and which of the characteristics of statehood they own.

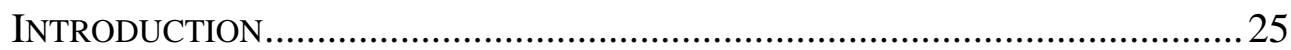

I. CONCEPTUAL DEFINITION OF SOVEREIGNTY............................................... 26

II. FIVE MANNERS TO ACQUIRE SOVEREIGNTY .............................................2

III. TERMS “DE JURE” AND “DE FACTO” RECOGNITION OF STATES ................28

IV. RECOGNITION OF STATES IN INTERNATIONAL LAW ..................................29

V. THE RULES OF INTERNATIONAL ORDER AND RECOGNITION OF STATES ... 30

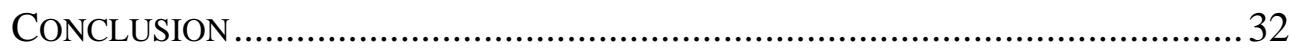

\section{INTRODUCTION}

The state as a subject of International law as a general notion is defined through its four basic characteristics:

- Population;

- Territory;

- Government and;

- Sovereignty.

The entirety of all citizens living within a certain territory, separated from other territories, which are subordinate to the government and have an established relationship with the state through legal connection-citizenship is called population.

The territory is an area separated from other areas by border, where a certain population lives and where a certain authority extends.

State boundaries are endpoints up until the sovereignty of a state

\footnotetext{
* Aneta Stojanovska-Stefanova, PhD Candidate, Teaching Assistant, Faculty of Tourism and Business Logistics, University Goce Delcev, Stip, Republic of Macedonia. Research fields: International Law and Politics, History of Diplomacy; Political System.

${ }^{* *}$ Drasko Atanasoski, Ph.D., Assistant Professor, Faculty of Tourism and Business Logistics, University Goce Delcev, Stip, Republic of Macedonia. Research fields: International Transport and Logistics, Costums Administrative Procedure.
} 
extends.

The authority within a country regulates the relations in the state and the nature of its international positions.

The highest authority, which does not recognize any other form of higher power is sovereignty ${ }^{1}$.

The characteristics of a modern state, the way it is recognized nowadays are shaped by Peace Treaty of Westphalia ${ }^{2}$, according to which the state is constituted by three main features, territory, population and sovereignty, i.e., absolute power for governining over them ${ }^{3}$. In order to have a better understanding of the process of recognition and various specifics that have occurred throughout history, the attention must be paid to the terms sovereignty and statehood first, and thereto sovereignty refers to how a state acquires it as well, and later on the manners through which countries recognize the existence of another state ${ }^{4}$.

\section{CONCEPTUAL DEFINITION OF SOVEREIGNTY}

Sovereignty denotes supreme and independent authority over certain territory and its population. This type of interpretation which is a part of a broader definition regarding the notion of state, plays a significant role in each aspect of the international relations and international law because it indicates that, no one else, referring to another state, has no right to impose and implement laws on the territory of a sovereign state. According to which, the law of using force aiming law enforcement depends solely on the governing organ, meaning the Government, the Presidents or a divided sovereignty between both institutions. Hence, if a state acquires sovereignty recognized by other states, they acknowledge its governing over a certain territory and population and withdraw the possibility to interfere the state internal matters they have recognized.

Sovereignty is generally divided into:

- Internal and;

- External.

Internal sovereignty is determined by the state organ with the authority

\footnotetext{
${ }^{1}$ Williams, Goldstein, \& SChfritz, Classic Readings of InTERnational Relations 82 (Belmond, California: Wadsworth Publishing Company).

${ }^{2}$ Peace of WestPhalia, Encyclopedia Britannica. Available at http://www.britannica.com (last visited July, 2013).

${ }^{3}$ The Crisis of the Sovereign State and the "Privatization" of Defense and Foreign Affairs (Heritage Foundation). Available at http://www.heritage.org (last visited April, 2012).

${ }^{4}$ Diplomatic ReCOGnition (Wikipedia) Available at http://www.wikipedia.org (last visited July, 2013).
} 
for exercising the power, while external sovereignty depict the role of the state as a sole in the international community, and the attitude towards the state as to the bearer of rights and obligations in relation to other states in international law.

Considering the significance of the term sovereignty, the importance and role of the decision whether a country will be internationally recognized or not is becoming clear, as well as the necessity of each territory and people aspiring to become state to provide the conditions for acquiring sovereignty.

\section{FIVE MANNERS TO ACQUIRE SOVEREIGNTY}

Sovereignty is generally acquired in five manners, out of which four are being recognized by the international law ${ }^{5}$.

The first manner is through settling to "no man's land" or land on which no one had previously claimed rights for sovereignty, or if it was under possession previously and this possessor has withdrew their sovereign rights over the country, thus removing the obstacles for a new or another country to realize its sovereignty over that territory.

The second manner is connected with the first and anticipates attaining of sovereignty, through the same exercise for a longer period on the territory without another state disputing that right.

Separation is the third manner through which the sovereignty can be attained, but it needs to be conducted in accordance with the state in which this separated territory has been part of. Thus the transfer of the rights from one to another sovereign is made in such way, most often through agreement, so the modern trends and arousing of the idea for selfdetermination impose the new sovereign to gain the consent from the population whose territory requests sovereignty before acquiring it. Such case represents the uniting on Eastern and Western Germany which was occupied by four countries-USA, France, Great Britain and Soviet Union. All of them have given a consent for implementation of this process and withdrew the sovereign right over its part from the German territory for which the citizens has expressed themselves positively.

The fourth one out of the mentioned five methods nowadays is not considered as a legal manner for attaining the sovereign, because it is based for acquiring what is announced as illegal by the United Nations, and as such is considered in its Charter that has been signed and ratified by each member state.

\footnotetext{
${ }^{5}$ Aneta Stojanovska, Process and Methods for Recognition of States, ANNUAL YEARBOOK-LAW FACULTY 267 (@-ri Avgust-Stip: Goce Delcev University-Stip 2009). ISSN 1857-7229.
} 
The fifth and the final type for setting the right for sovereignty over certain territory concerns if it is established as an additional part of already existing territory, through a manner of natural growth such as sedimentation or volcanic activities.

\section{TERMS “De JURE” AND “DE FACTO” RECOGNITION OF STATES}

Considering the fact that, the law, especially the international law is an active matter open for interpretation even though the basic characteristics in one state are clear, yet there are two types of states divided into: de jureexisting according the law and de facto- existing in reality, based on the fact which of the statehood features they $\mathrm{own}^{6}$.

De jure states are those that are fulfilling some of the conditions of statehood but not all three. As an example can be considered, a country that has a territory and a population but not full sovereignty over them. Also a good example could be a government in exile as well, or government under which the international community has the right to exercise sovereignty over a territory and a population but because of the occupation can not exercise that right, as is the case with the governments of the Baltic states in the period during World War II, while their territories were under Nazi occupation, they are recognized by the countries of the alliance as their legitimate rulers, role which de facto was taken over after the release. Another specific example of recognized sovereignty in the absence of territory in some way but not completely de jure state but rather as de jure government is the sovereignty dealing with "the organization" known as the Sovereign Military Order of Malta.

This "organization" had an authority in Malta in the past, but after the expulsion of its members from the island, they continue to exist in Rome. Interestingly, the Order is recognized as sovereign by many countries, a situation that reflects the fact that, it has established diplomatic relations with 103 states and 6 entities that are subject to international law, including the European Union whereby they have responded with reciprocity that have established diplomatic relations with the Order. Apart from diplomatic relations, the Sovereign Military Order of Malta has few buildings in the city of Rome that, the Italian Government has granted their extraterritorial status which means that, within the territory/facilities, the law is implemented by the Order, and not by Italy, and this is a status reserved exclusively for the embassies of countries. In addition the United Nations does not register the Order of Malta as “a non-member”, but as an entity that

\footnotetext{
${ }^{6}$ Ibid, at 268 .
} 
has received a valid invitation to participate as an observer in the organization. Apart from these typical state features "the organization" has its own army, which is part of the Italian Army, however flying the flag and under the command of the Order; it also has coins that have rather collectors than a symbolic role and uses postal stamps, although not everywhere yet accepted by a number of European and world countries.

De facto state is considered the one that is an entity owning a territory and a population and sovereignty, but which lacks a legitimate recognition by a number of other states. This usually happens if a de facto state has been part of another country previously that opposes and denies its sovereignty. Here lies the tangent point between the characteristics of statehood and the need for their recognition as legitimate by other, already existing countries. There are many examples of de facto countries in the world including Taiwan, which the People's Republic of China considers it as part of its territory even though there is no real sovereignty over it, as is the case of Somaliland and Somalia, to some extent Kosovo and Serbia etc.

\section{RECOGNITION OF STATES IN INTERNATIONAL LAW}

The Institute "recognizing the states" is common and very important legal institution within the International Law initially, because of the political circumstances which are determining it ${ }^{7}$. Up until now, there is not precise rule accoriding to which one state becomes internationally recognized, and has the right of statehood and right to participate as single with the other states from different imternational organizations ${ }^{8}$. There are some attemts made in order to establish certain universal criteria for acquiring the aforementioned statuses and possibilities but none of them has succeded to be affirmed as a relevant and respected by all the states in the world. There are two theories that study this matter ${ }^{9}$. The first one is the Declarative Theory of statehood, originating from the conference held in Montevideo $^{10}$, which is best put in the sentence "the political existence in one state is independent from its recognition by other states".

According to this theory for acquiring statehood, and thus the involvement of the state in international law as its subject, the following four element must be included: territory, population, sovereign power and

\footnotetext{
${ }^{7}$ LJ. D. Frckoski, V. Tupurkovski, \& V. ORtakovski, InTERnational Public LAW 58 (Tabernakul, Skopje 1995).

${ }^{8}$ Additional information at: Thomas D. Grant, The Recognition of States: Law and Practice in Debate and Evolution, (Praeger Publishers 1999).

${ }^{9}$ Additional information at: H. Lauterpacht, Recognition of States in International Law, YALE LAW JOURNAL (New Haven Conn. 1944).

${ }^{10}$ Additional information at: Montevideo Convention on Rights and Duties of States, (1933).
} 
ability to manage the previous three. Going back to the beginning of this text, it can be seen that, the largest part of the definition is taken from the Treaty of Westphalia, which means that, it is not a novelty in international law, but an existing criteria which although recognized it is not fully accepted and implemented free from discrimination.

International law includes Constitutive Theory of statehood. It examines the state recognition by other states as instrumental in acquiring statehood and status of a subject of international law to a new country. The aspects that are covering this theory, which although not formally accepted worldwide but can be considered as realistic are beautifully depicted in the thought of Openheim (L. Oppenheim) that says "International law says that, a state does not exist until it is recognized by other, but at the same time, it does not exist until it acquires recognition.”

It can be concluded that, the acquisition of independence and international legal subjectivity of a state is formally dependent on its international recognition, which is based on the will of other countries.

Sublimating the declarative positions of states as for this subject and reality of the foregoing, it can be concluded that, the recognition of a state as a sovereign entity and relevant international law is open to interpretation, there are no rules in this field and any existing state recognized a new state on its own discretion and in accordance with its national interests, while not obligatory adhering to certain customary norms in international behavior.

\section{The Rules of INTERNATIONAL ORDER AND RECOGNITION OF STATES}

After noting that, the recognition of states in international law is a matter of political decision, lets consider the methods by which it is awarded ${ }^{11}$. Seemingly with the classification of the de jure- states and de facto-states, both models exist as methods of recognition. De jure recognition means having a formal legal act-a diplomatic note, law or declaration, often in the legislature or by the government or head of state, which through an official document is published on a recognition by one state over another ${ }^{12}$. This method is ambiguous and is not free for interpretation.

The second method, de facto implies the establishment of political, economic and other types of relations.

The differences between the first and second lies in the formal legal document which results with rights and obligations, which in the first case is present, and but not in the second one.

\footnotetext{
${ }^{11} 35$ InTERNATIONAL \& COMPARATIVE LAW QUARTERLy 975-990 (Cambridge University Press 1986).

${ }^{12}$ 4(1) EUROPEAN JOURNAL OF INTERNATIONAL LAW 66-71 (1993).
} 
De facto recognition is often used in order to avoid disruption of bilateral relations with another state, but also to implement actual recognition of the state. The manners of relations between two states that can be seen as steps towards recognition are: the establishment of diplomatic relations, the visiting of head of state at the country which requires recognition, bilateral agreements between both countries and the recognition of the passports of this country that is recognized by the existing state. Seen throughout the history there are cases in which diplomatic communication between the two countries have been necessary, one of which is not recognized internationally, as is the case in the establishing of the dialogue between the United States and the Palestinian independence movement, which, to avoid sending an informal message for recognition, the existing state explicitly states that, its activities do not imply to recognition of the state which due to certain reasons temporarily establishes relations with that state. A similar example is the relationship of Taiwan by a number of countries. While officially recognized and has diplomatic relations with only 23 countries, unofficially in Taiwan there are research offices and cultural centers and trade associations covered by the United States, Australia, Britain, France and many other countries.

According to the doctrine introduced in the thirties of the twentieth century by Mexican Minister of Foreign Affairs, Genaro Estrada, except previous two methods of recognition of states introduces a third one. What's the difference? If the policy of the state is to perform legal recognition, it means that, at any unconstitutional change of the goverment within the state, it must come up with a statement that expresses positive or negative attitude in terms of recognizing the new government ${ }^{13}$.

The advantage of this policy is the possibility of revising the attitude towards other countries at any unconstitutional change, but it means interfering in its internal affairs through the approval or disapproval of the changes. The policy of tacit recognition is a balance between the other two doctrines and according to it, the state is not obliged to assess new government of another country, but if it is willing, may confirm or withdraw the recognition. The third doctrine, which is most frequently used nowadays, refers to recognizing states rather than governments. Thus if the first state has recognized the state where unconstitutional change of government occurred, they will not review the decision for recognition based solely on the change of the regime. The advantages of this policy are far lower administrative and bureaucratic procedures through the political changes that are taking place worldwide. However there are deficiencies which are

\footnotetext{
${ }^{13}$ Aneta Stojanovska, Process and Methods for Recognition of States, ANNUAL YearbooK-Law FACULTY, 272 (2-ri Avgust-Stip: Goce Delcev University-Stip 2009). ISSN 1857-7229.
} 
consisted of leaving room for maneuver, in case there is a real need to review cooperation with the country in which the change occurred.

As a special form of recognition could be considered also the so-called "Collective recognition of states" that can occur through common acceptance of membership of a country in the regional and universal international organizations, through common acceptance of the declaration at the international conference or through a formal procedure in the bodies of the international organization.

The recognition of a state internationally is depicted through its membership in the United Nations (UN) ${ }^{14}$. With the membership at this world organization, every dilema about the independence and sovereignty of any country is being eliminated. That is so because becoming a member of this international institution is necessary to achieve the recognition of the five member states of the Security Council, such as the US, Russia, China, Britain and France, and without their decision (resolution), it is not possible to achieve membership.

But it is important to point out that, there is no requirement (in the UN Charter) which obliges Member States, upon the acceptance of a new state membership in the UN, to establish "full political and legal recognition" through the establishment of bilateral diplomatic relations ${ }^{15}$.

\section{CONCLUSION}

The entirety of all citizens living within a certain territory, separated from other territories, which are subordinate to the government and have an established relationship with the state through legal connection-citizenship is called population. The territory is an area separated from other areas by border, where a certain population lives and where a certain authority extends. State boundaries are endpoints up until the sovereignty of a state extends.

The authority within a country regulates the relations in the state and the nature of its international positions. The highest authority, which does not recognize any other form of higher power is sovereignty.

The Institute "recognizing the states" is common and very important legal institution within the International Law initially, because of the political circumstances which are determining it.

\footnotetext{
${ }^{14}$ Further information at: HANS Kelsen, The LAw of THE United NATIONS. Available at http://www.un.org.

${ }^{15}$ LJ. D. Frchkoski, V. Tupurkovski, \& V. ORTakovski, International Public LaW 61 (Tabernakul 1995).
} 
Considering the fact that, the law, especially the international law is an active matter open for interpretation even though the basic characteristics in one state are clear, yet there are two types of states divided into: de jureexisting according the law and de facto- existing in reality, based on the fact which of the statehood features they own. 